試料と同じ比容積を有するようになる。

(4) 常温付近では，10分間の放置で残留応力の大部分 を緩和してしまう。

(5) 温度差が大きいほど，たくわえられる残留応力は 大きい.

(6) 本実験に使用した、インレーワックスの比容皘 は，15ํで1.0413となった。

\section{4. 半調節性咬交器における関節球誘導路の臨床的観} 察

$$
\begin{gathered}
\text { (九米大 } 1 \text { 補) } \text { ○豊田静夫 } \cdot \text { 高山康男 } \\
\text { 伊藤好二 }
\end{gathered}
$$

機能的形態を有する総義歯を製作するには，人工歯の 咬合面に対して自動削合を行なわなければならない，自 動削合には口内法と口外法があるが，口内法は直接患者 の顎を咬交器として利用できる点は理想的である。しか し，総義霜が弾性のある粘膜上飞装着されること，执よ び口腔内の生理的，解剖的諸因子の影響により削合時に おける義歯の動摇はま奴れない，そのため顎運動路に 調和した適切な咬合小面を形成することは非常に困難で あり，あらかじめ，可成り忠実に顎運動を再現できる機 能咬交器を用いた口外法による自動削合が必要である。 自動削合に用いられる咬交器には, 完全調節性咬交器, 半調節性咬交器, 平均值咬交器などがあるが, 使用法が 割合簡単で，しかる必要な範毌の顎運動を可成り正確に 再現できる半調節性咬交器が最す広く用いられている。

このたび, 半調節性咬交器を選び, その中で, 顎運動 の再現性，並びに自動削合に最屯関係が深い関節部の構 造, 特に関節球誘 導路に特 徽のある三種の咬交器, 即 ち, 呯根式咬交器, Hanau $\mathrm{H}_{2}$ 咬交器, Whip Mix 㕮交 器を用い， 1) 肉眼的に観察した関節球誘導路の構造 上の相違点，2）口内法により顆路を測定した場合， その標示角度に影響を与える所の咬交器に作業模型を附 着する基準面の相違点（顔弓による計測部の相違）。

3）口内顆路測定法（Check bite法を用いる）に用いら れるWax，並びに術式．などの諸点について臨床的に検 討した結果について報告した。

\section{5. 局部義歯維持に応用した軟性樹脂の1臨床例}

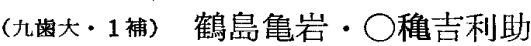

椿，幸雄

少数崡残存の局部休義歯の症例において，その残存画 を鈎曾として利用しようとしても通例のクラスプでは床 の維持を期待できない場合がある。
症例 I $\overline{321 / 123}$ が残存し両側臼雬部歯槽堤の 吸収が著しく義歯の安定に好ましくない雪槽形態をなし

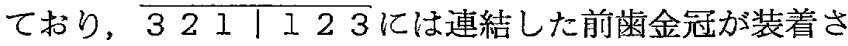
れ，その歯冠形態は円錐状をなしクラスプによる維持力 を期待できそうにない状態である，反面，歯槽部唇面に は大きなアンダーカットが認められた，乙の症例に鈎用 弾力線之軟性樹脂之を組み合わせて弾性歯肉鉤を調製し 義蒾の維持力を高めることができた。

症例 $2 \sqrt{8}$ のみが残存し，しかも舌側傾斜が著しく鈎 蒾として利用できない状態で，しかす患者に心臟疾患が あり抜歯の禁忌状態である。なお左側臼歯部から後臼歯 部にかけて，歯槽部舌側に大きなアンダーカットが認め られた。 この症例に対し鉤用弾力線と軟性樹脂とにより 弹性霜肉鈎類似の維持装置を調製し義雬の安定を得るこ とができた。

以上のように何らかの理由で残存歯にクラスプを応用 し難い症例で歯槽部に大きなアンダーカットの存在する 場合に，軟性レジンと弾力線を併用して維持装置を調製 し義㐘の安定を得ることができた，軟性レジンは義歯着 脱時並に機能時に粘膜に対して緩圧的な作用を期待でき るので, 粘膜に疼痛や潰瘍形成等の為害作用を与えるこ とが少なく予後が良好である。

\section{質 疑}

(福网市) 坂 牧

1，軟性レジンを支える金属線の銘柄

2. 軟性レジンの寿命基礎となるアクリルレジンのよ う永久使用侕耐えるか.

3軟性レジンと基礎床レジンとの結合はどうするか.

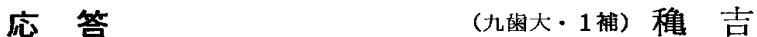

1. 現在軟性樹脂の耐久性については予後観察中.

2 弾力線のみによる荬肉鉤は雬槽部を把握する場合 粘膜面を圧迫して潰瘍形成等のトラブルを起し易い，軟 性樹脂には緩圧的な作用を期待し得るので粘膜に対する 压刺激が少なくてすむ。

3 シリコンをべースとした弾性裹装材を使用した。 商品名ニュー・スナッガー、レジン床との結合には尃用 の接着材を使用する.

\section{6. 鋳造冠の機能的咬合面形成法について} (九愾大. 2 赤) ○松浦智二 . 内田康也 黒岩整二・荒川 治 原 健治

近年補綴臨床においてクラウン・ブリッジ製作に関し 